\title{
Disseminated cysticercosis: whole body MRI
}

\author{
Jyoti Kumar, ${ }^{1}$ Suchita Gorghate ${ }^{2}$
}

${ }^{1}$ Department of

Radiodiagnosis, Maulana Azad Medical College, New Delhi, India

${ }^{2}$ Maulana Azad Medical

College, New Delhi, India

Correspondence to

Professor Jyoti Kumar, drjyotikumar@gmail.com

Accepted 19 June 2015

\section{DESCRIPTION}

MRI of the brain and short tau inversion recovery (STIR) coronal imaging of the whole body were performed on a 49-year-old man, who presented with multiple episodes of generalised tonic clonic seizures, generalised muscular hypertrophy and muscle-ache of 3 months' duration.

Brain MRI revealed multiple discrete nodular lesions showing variable signal intensity scattered diffusely in a miliary pattern throughout the brain parenchyma. The lesions appeared hyperintense on T2-weighted images (figure 1A) and hypointense on T1-weighted (figure 1B) images, with an eccentric hyperintense focus within most. A few lesions showed perilesional oedema and some showed calcification within, which was seen as blooming on flash images (figure 1C). Similar lesions were also seen involving the ventricular system and ocular and tongue muscles (arrows in figure 1B), and scalp muscles (arrow in figure 1A). Findings revealed disseminated cysticercosis in various stages of their life cycle. Whole body STIR coronal images (figure 2A-C) depicted cysticerci involving almost every muscle of the body. The muscles appeared bulky and the cysticerci were clearly seen as hyperintense nodules against the dark background of muscle.

The patient was started on anticystoidal treatment with oral steroids and antiepileptics, which helped in stabilisation of the clinical condition.

Cysticercosis results in humans after ingestion of Taenia solium eggs, usually orally from eggcontaminated food or water, or through inhalation of egg-bearing matter. Disseminated cysticercosis, involving the brain, tongue, orbit and almost every muscle of the body, as in our case, is a rare and lifethreatening disease, with very few cases reported in the literature. ${ }^{1-3}$ Diagnosis of intramuscular cysticerci involvement is difficult clinically as these are usually deep seated and difficult to palpate. Whole body MRI is a very useful and safe modality for diagnosing this condition, and leads to timely management and the circumvention of invasive tests. Pretreatment with corticosteroids before the use of cysticidal drugs decreases the incidence of associated anaphylactic complications.
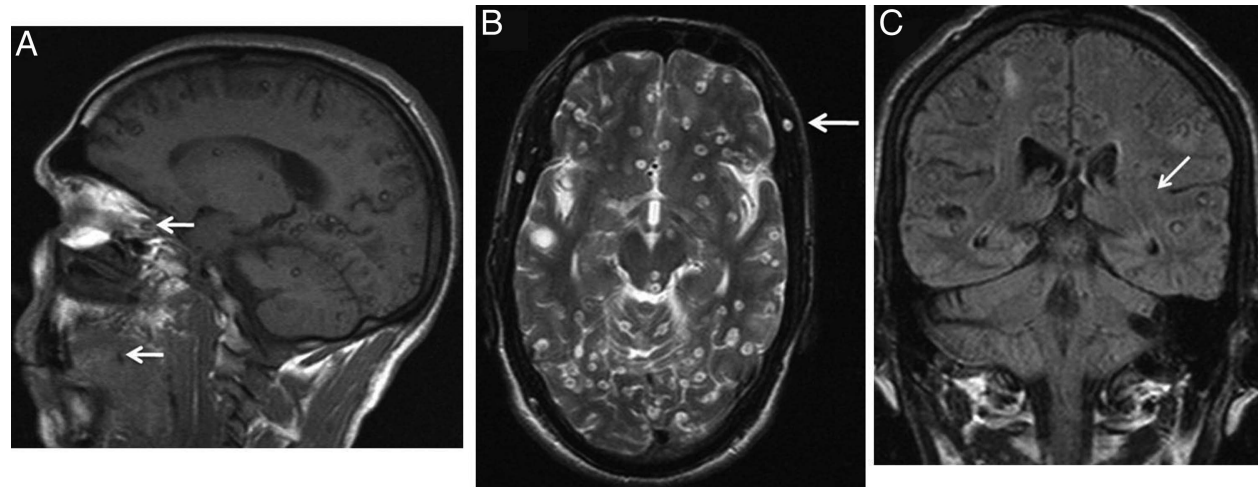

Figure 1 (A-C) T1 weighted sagittal (A), and T2-weighted axial (B) and FLAIR coronal (C) MRIs of the brain showing disseminated cysticerci with an eccentric hyperintense focus within most, and a few showing oedema (arrow in C). Similar lesions are seen involving ocular and tongue muscles (arrows in B), and scalp muscles (arrow in A).
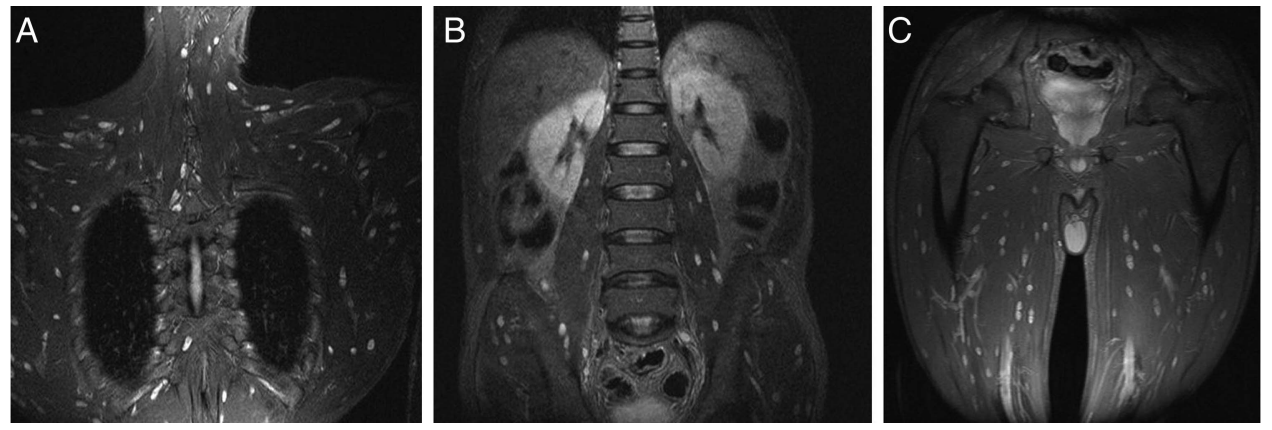

Figure 2 (A-C) Whole body short tau inversion recovery (STIR) coronal images depict bulky muscles with cysticerci seen as hyperintense nodules within. 


\section{Learning points}

- Disseminated cysticercosis is a rare and life-threatening disease and clinical diagnosis is often difficult, as these are usually deep seated and difficult to palpate.

- Whole body MRI is a very useful and safe modality for diagnosing this condition and helps in its timely management.

Contributors SG was involved in the conception and design, drafting the article and final approval of the version to be published. JK was involved in the conception and design, or analysis and interpretation of data, revising the article critically for important intellectual content and final approval of the version to be published.

Competing interests None declared.

Patient consent Obtained.

Provenance and peer review Not commissioned; externally peer reviewed.

\section{REFERENCES}

1 Jawale R, Duberkar D. Disseminated cysticercosis. Neurology 2015;84:327.

2 Kumar A, Goenka AH, Choudhary A, et al. Disseminated cysticercosis in a child: whole-body MR diagnosis with the use of parallel imaging. Pediatr Radiol 2010;40:223-7.

3 Pushker $N$, Mehta $M$, Meel $R$, et al. Disseminated cysticercosis with multiple bilateral orbital cysts. Ophthal Plast Reconstr Surg 2009;25:499-501.

Copyright 2015 BMJ Publishing Group. All rights reserved. For permission to reuse any of this content visit

http://group.bmj.com/group/rights-licensing/permissions.

BMJ Case Report Fellows may re-use this article for personal use and teaching without any further permission.

Become a Fellow of BMJ Case Reports today and you can:

- Submit as many cases as you like

- Enjoy fast sympathetic peer review and rapid publication of accepted articles

- Access all the published articles

- Re-use any of the published material for personal use and teaching without further permission

For information on Institutional Fellowships contact consortiasales@bmjgroup.com

Visit casereports.bmj.com for more articles like this and to become a Fellow 